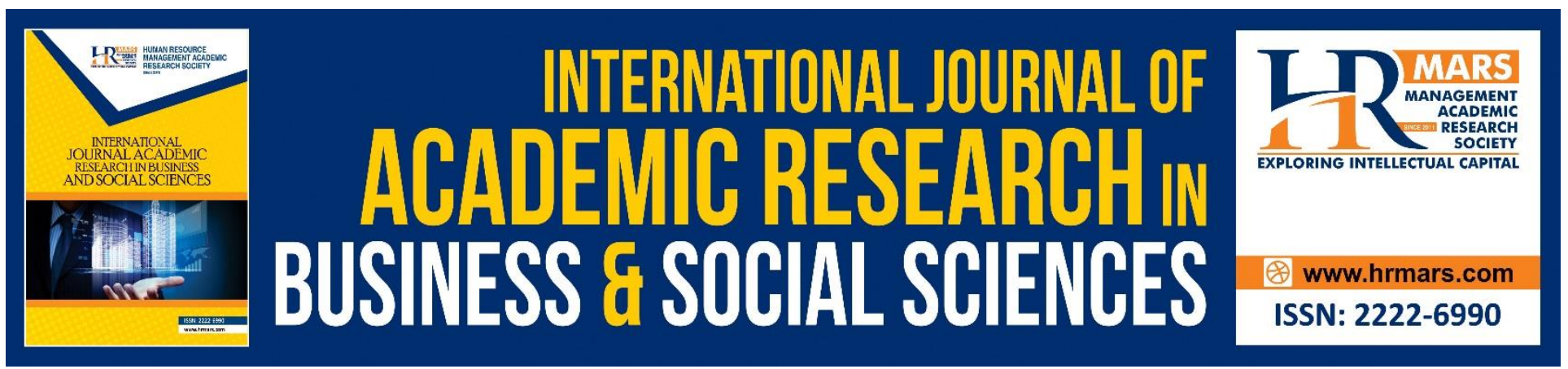

\title{
Poverty Eradication through Productive Welfare Approach in Malaysia
}

Zakiyah Jamaluddin, Norzalinda Mohd Ali Hanafiah

To Link this Article: http://dx.doi.org/10.6007/IJARBSS/v8-i9/4690 DOI: $10.6007 / I J A R B S S / v 8-i 9 / 4690$

Received: 06 August 2018, Revised: 29 August 2018, Accepted: 19 Sept 2018

Published Online: 15 October 2018

In-Text Citation: (Jamaluddin \& Hanafiah, 2018)

To Cite this Article: Jamaluddin, Z., \& Hanafiah, N. M. A. (2018). Poverty Eradication through Productive Welfare Approach in Malaysia. International Journal of Academic Research in Business and Social Sciences, 8(9), 1186-1192.

Copyright: (C) 2018 The Author(s)

Published by Human Resource Management Academic Research Society (www.hrmars.com)

This article is published under the Creative Commons Attribution (CC BY 4.0) license. Anyone may reproduce, distribute, translate and create derivative works of this article (for both commercial and non-commercial purposes), subject to full attribution to the original publication and authors. The full terms of this license may be seen at: http://creativecommons.org/licences/by/4.0/legalcode

Vol. 8, No. 9, September 2018, Pg. 1186 - 1192

Full Terms \& Conditions of access and use can be found at http://hrmars.com/index.php/pages/detail/publication-ethics 


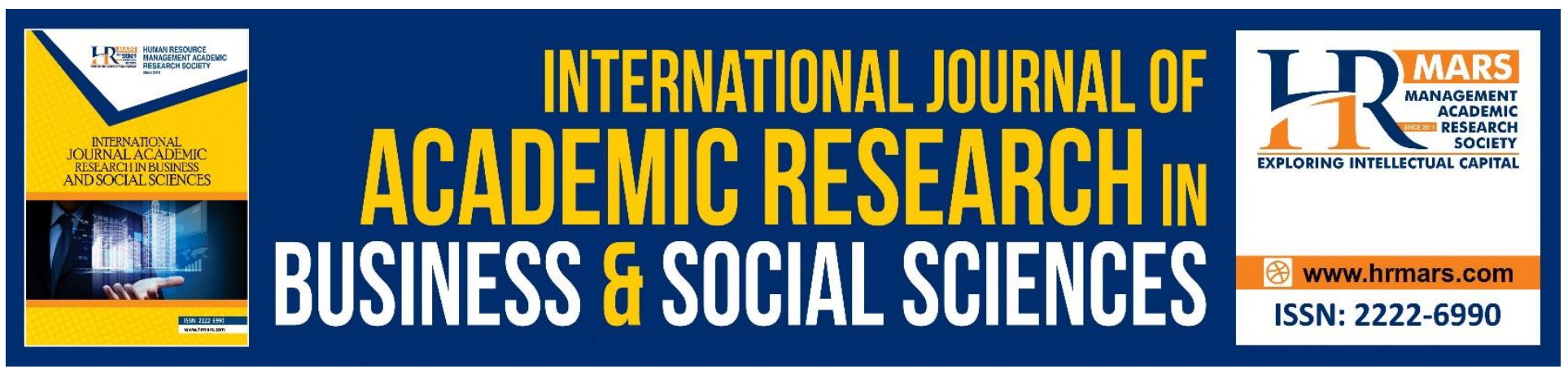

\title{
Poverty Eradication through Productive Welfare Approach in Malaysia
}

\author{
Zakiyah Jamaluddin ${ }^{1}$, Norzalinda Mohd Ali Hanafiah ${ }^{2}$ \\ 1,2Social Work Program, School of Applied Psychology, Social Work \& Policy \\ University Utara Malaysia, Malaysia \\ Email: zakiyah@uum.edu.my
}

\begin{abstract}
Poverty has become one of the social problems in Malaysia. However, since Malaysia government launched the New Economic Policy (NEP) in 1970, the poverty rate and incidence decreased over the years. There were many approach that has been used by the government to eradicate poverty, including aided the poor by financial assistance supported by the Malaysia Social Welfare Department (MSWD), one of the government agency. In 2010, the MSWD took an effort to initiate the Productive Welfare approach to help the financial assistance recipients to increase their income through entrepreneurial activity. It is hope that this approach will help them to become independent without depending on the financial assistance anymore, once they exit the poverty line. The Productive Welfare approach has been widely used in the western countries and South Korea to curb the poverty issues and at the same time to help the poor to be independent without depending on the government's aid. It is hope that this approach will help the poor to sustain and enhance their social functioning and the quality of life.
\end{abstract}

Keywords: Financial Assistance, Poverty, Poverty Eradication, Productive Welfare, Recipient

\section{Introduction}

As of 2010, the Malaysia Social Welfare Department (MSWD) is committed in effort to realize the Productive Welfare Approach envisaged in the $10^{\text {th }}$ Malaysia Plan. Prior to this, all forms of assistance given by the MSWD to the recipient were to help them to increase income and eradicate poverty. By 2015, the MSWD hope that the financial services would then become a transitory service for recipients to achieve quality in living standard and be a contributor towards sustainable socioeconomic changes among them. This approach subservice to raising the recipient's motivational preparedness to work, after receiving training in skills commensurate with their ability. The recipient's participation in the working environment would be on a continuous basis to ensure their survivability and independency from further welfare support. 
One of the strategies used by MSWD is giving a launching grant of Malaysian Ringgit RM 2,700. This is on shot cash financial assistance to the recipients wishing to engage in entrepreneurial activities. This article attempts to look at the strategy utilized by the MSWD towards the financially assisted recipients namely the clients. It is also helped to be able to realize the objective of the MSWD to apply the Productive Welfare approach as a new mechanism to rise the social functioning of those assisted financial recipients.

Indirectly this is also inline with the government's aspiration through field of focus in the fourth objective of the National Key Result Areas (NKRA), which is to raise the income level of the low income group. It is also inline with the 2020 target aspiration for a fair social achievement in the society including of dynamism, wealth and competiveness.

\section{Poverty in Malaysia}

Poverty encompasses situations of hunger, shortages, and homelessness, sick without opportunity to get medical help and no access to education. Poverty also included those unemployed, fearing for their future and existing on a day basis. Poverty also portrayer's situations whereby someone has lost their right and defenseless (The World Bank Annual Report, 2008).The world's poverty scene sees $9.6 \%$ of the whole of the world's populace as of earning USD 1.90 daily (World Bank, 2016).

Shostak and Gomberg (1965) define poverty even more widely as a complex phenomenon comprising personal experiences, economic problem psychology, social and the individual's political level. The more generally accepted definition of poverty is the approach relating to income. Poverty here is having insufficient income or money source to fulfill one's basic needs as well as to be at the minimum level of living requirement provision (Sharp, Register and Grimes, 2003; Singer, 2006; Misturelli \& Heffernan, 2008).

The measure of poverty in Malaysia relies on the Poverty Line Income (PLI). For example the PLI in 2007 for the Peninsular of Malaysia was RM 700 (Economic Planning Unit, 2007). Hence households with income of less than RM 700 were categorized poor. Otherwise household with income of RM 700 were not deemed poor (Siti Hadijah Che Mat, Roslan A.Hakim \& Siti Norliza Jumali, 2012).

Studies by Siti Hadijah, Roslan and Siti Norliza (2012) found that appropriate and accurate approach to poverty need to be made to address the problems of poverty according to its requirements to more effectiveness achieve poverty eradication objective. The study finds although poverty exists in multi dimensions its focus is on individual's well-being. This well-being is not only seen on income alone but also on other dimensions like health, education, employment and other factors.

Siti Hadijah et al. (2012) also found that effort to eradicate poverty since the Independence of Malaysia 1957 has been the main agenda of New Economic Policy (NEP) introduce in 1970. Generally the poverty in Malaysia has successfully been reduced by a big margin from $52.4 \%$ in 1970 to $3.8 \%$ in 2009, and $0.6 \%$ in 2014 (Malaysian Fundamental Data, 2014) and down to $0.28 \%$ on 2016 (www.bicara.news, 2016). In the $10^{\text {th }}$ Malaysian Plan2010 - 2015, the poverty rate has fallen to $2 \%$, and the average income for 40\% of lowest income households have risen from RM 1440 in 2009 to RM 2300 in 2015 (10 ${ }^{\text {th }}$ Malaysian Plan, 2010).

\section{Malaysia Social Welfare Department (MSWD) Role to Eradicate Poverty}


The groups of poor and poorest in Malaysia are still dependent on government's aid via the MSWD. It is not cozy to get an accurate figure on the number of recipients who were assisted by the MSWD as each state in Malaysia keeps their own record. However, in practice, the data on the groups of the poor can be accessed through the e-Kasih system, a data based system created at national level to help in the planning, execution, and monitoring of poverty program. The people who fulfill's the poverty criteria for the status of poor are based on the per capita household income PLI 2007 being RM 830 in the Peninsular Malaysia, RM 1090 in Sabah and RM 920 in Sarawak (Ministry of Women, Family and Community Development, 2015). Additionally other groups eligible to register and have their data in e-Kasih are those households with income of less than RM 1000 per month in rural areas and less then RM 1500 for those living in the urban areas (Kedah SWD website, 2015).

The purposes of financial assistance provided by MSWD are to supplement income to fulfill daily needs, raising standards of living and as a boosting allowance for the target groups [namely the handicapped, single mother, and their clients of the (MSWD) to case them into gainful employment and finally become independent. The objective would be to assist the individuals or families in need and needy towards reducing their financial hardships for a brief period until they are financially independent (MSWD, 2015).

MSWD Strategies towards Financial Aid Recipients and Their Productive Welfare The productive welfare approaches are not new as many western countries have long adopted productive welfare in their welfare system budgets. Hudson and Kuhner (2009) has studied 23 countries in the Organization for Economic Cooperation and Development (OECD) that practices productive welfare and productive element in their social policy, in three different period of years i.e. 1994, 1998 and 2003. Most of the analysis suggested that the globalization process and k-economy (knowledge based economy) have encouraged many developed countries to push towards productive welfare with a focus on social investment. However welfare typology typically tends to social protectionism as opposed to social investment. The result of the studies by Hudson and Kuhner (2009) found that many welfare states are changing their protective approaches into the direction of welfare, and some countries combined the two approaches in their social policies.

Meanwhile Hudson, Kuhner and Yang (2014) evaluate the welfare state models relevant to China. Specifically they analyze literatures on welfare models issues of East Asia as well as arguments on productive welfare models. Their studies found that generally there are a variety of form of welfare in East Asia and the Chinese Mainland.

It seems South Korea have already embraced the practice of Productive Welfare since 2000. The Productive Welfare Concept influenced by the British Third Way approach introduced by Anthony Giddens (Han, 2002; Kim, 2003; Sung, 1999). The economic recession crises of 1997 prevented South Korea from continuing to provide direct financial assistance to the people. Instead their financial aid changed from welfare to employment. Other than protecting the handicapped and the marginalized groups of the community in its welfare system, the state created employment opportunities to the recipients. Indirectly this approach transformed aids of pure welfare to a system of marketability cum welfare. As a result, the National Basic Livelihood Security System (NBCSS) Act was introduced in 2000 to wider the targeted recipients to include those already in employment also to be eligible to receive income support from the state (Cheon, 2003; Jisun, 2008; Jo, 2007; 2014). 
Normally financial assistance is seen as a long term program of sustainable dependency and generally the recipients are viewed as not independent and problematic. Hence the MSWD committed efforts to realize the approach of productive welfare as meant by the agenda of the $10^{\text {th }}$ Malaysia Plan commencing in 2010. Productive Welfare is a holistic human development approach stressing the individuals consciousness attitude change, good work ethics, new skill as well as improving existing skill sets and capacity building. The aim is to transform the recipients from the attitudes of negativity towards a wholesome able, confidence and independent individual.

Productive Welfare is an approach to assist those receiving financial assistance to be independent and able to survive; to escape the life of continuous dependency by empowering clients to be independent. It is also to activate programs toward human capital development.

The productive welfare section was created on January 2014 following the MSWD restructuring exercise; it was probably called the Social Economy Development and Assistance Section. Starting from 2017, the new section consists of 4 main branches being the Assistance Management Section, Productive Client Development Section, the Disaster and Crisis Section and the Social Entrepreneurial Section (MSWD website, 2016).

The main objective of the Productive Welfare are to firstly assist poor families and the extreme poor as listed in the e-Kasih system (a database for the poor and extreme poor families in Malaysia) and the clients of financial assistance recipients of the MSWD to lead a life of independency without having to result purely on government aid.

The e-Kasih system is the National Poverty Data Bank. It contains information on poverty starting with the individuals profiles, program/aid receive by the households head and members of the households beginning from the agency giving the assistance and into the applications for the assistance, and to the monitoring on the effectiveness of the assistance provided (programs / aids). Secondly, to alleviate poor families and the extreme poor's registered and listed as the recipients of welfare financial aid from the poverty status towards getting household incomes excluding poverty lines.

Thirdly to help financial assistance recipients to create opportunities to generate stable sources of income and become independent as well as achieving a quality well-being

And fourthly to create a network of corporation of the various private and public sector in effort to restore assists clients toward becoming independent.

Human capital is the main element that moves and executes plans to achieve its deserved purpose. Any plans attempting for positive change would not be effective thorough unless human capitals are factored in. Hence it is vital for any approaches in programs of productive welfare to be supported by having a ready work force as human capital to get it moving from grass root level.

This approach includes raising the client's motivation to be ready to work upon getting skills training suitable to their ability. The clients' involvement in work must be on going to prevent their return for welfare help (financial assistance) for living. To ensure this objective comes to fruition, MSWD hopes clients of this program could be taken out from the list of monthly assisted recipients and be readied to be independent within 2 years by an approach known as 2 years Exit Policy (2YEP). This policy was incorporated within the $11^{\text {th }}$ Malaysia Plan. One of the Productive Welfare strategies is to provide recipients with a starting off grants of RM 2700 in one lump sum to the clients to begin any entrepreneurial activity. 
Four criteria's are used to mark clients as Productive (Productive Clients). Those are based on health (healthy in physical and mental health), age (between 18 to 55 years), empowerment (motivated, able to work and potential for development toward self-independence and priority is given to clients already in business/ work project), and aid scheme (with a focus to financial aid recipients namely Children Assistance Handicapped Worker's Allowance, with priority given to recipients with income range of RM 900 to RM 1200; and General Aid (MSWD, 2016).

Successful clients would then be made role models for other assisted recipient clients. They would also serve as support group for other assisted clients. MSWD will also create Alumni for successful clients and launch a Welfare Entrepreneur Convention. The Alumni will be registered with the registrars of association to make it actively in helping the poor and the extreme poor clients.

Pragmatically, the MSWD would not deny the existence of few obstacles in the productive welfare program. Namely the absence of a special officer in the districts social welfare departments to monitor and supervise the running of programs to remedy recipient clients. The issue arises as current case workers are unable to execute the program as all are overburdened with current aid services to existing target groups. This approach is important to identify how far the objective of productive welfare could be reached. It also attempts to explore problems encountered by aid recipients in becoming entrepreneurs and their resilience in handling the problems.

\section{Conclusion}

The productive welfare approach looks to strengthening the clients i.e. AID recipient and motivation to be ready to work upon completing / receiving skill trainings suited to their ability. The ongoing involvement of clients in gainful employment is expected to ensure clients would not revert to living on welfare aid. Nonetheless MSWD would not deny the existence of resistance in executing the productive welfare program. Specifically the non-availability of a special officer to monitor and oversee the smooth running of the new operation could be a problem to the productive welfare approach. Currently the available case workers are not able to run the program as their current workloads, servicing their target group is huge.

Productive welfare is a new approach in Malaysia. It aims to change the beneficiaries' mentality towards a more independent and not only depends on government's financial assistance. Hence, entrepreneurial approaches are an effective way to enable beneficiaries to live independently. In addition, there has been no study on productive welfare in Malaysia. Therefore, this study can contribute significantly to productive welfare in Malaysia. At the same time, it can improve the standard of living and the survival of the poor.

\section{Acknowledgements}

The authors wish to thank the Ministry of Higher Education Malaysia in funding this study under the Fundamental Research Grant Scheme (FRGS), S/O code 13254, and Research and Innovation Management Centre, Universiti Utara Malaysia, Kedah for the administration of this study.

\section{References}

Cheon, E. S. (2003). Health and Welfare. Daekyengbooks. 
INTERNATIONAL JOURNAL OF ACADEMIC RESEARCH IN BUSINESS AND SOCIAL SCIENCES Vol. 8, No. 9, Sept. 2018, E-ISSN: 2222-6990 @ 2018 HRMARS

Han, S.-J. (2002). The Third Way of Korea (Hankookhyung je sam ui gil ul saengakhanda). Policy Forum, Spring, 4-19.

http://www.bicara.news/kadar-kemiskinan-malaysia-jatuh-ke-paras-0-28-bankdunia/(http://www.talk.news/ malaysia- poverty-rate-drop-to-0-28-world-bank/

Hart, P.L., Brannan, J.D. \& Chesnay, M.D. (2012). Resilience in nurses: An integrative review. Journal of Nursing Management, 22(6), 720-734. Doi: 10.1111/j.1365-2834.2012.01485.x

Hudson, J. \& Kuhner, S. (2009). Towards productive welfare? A comparative analysis of 23 OECD countries. Journal of European Social Policy, 19(1), 34-46.

Hudson, J., Kuhner, S. \& Yang, N. (2014). Productive Welfare, the East Asian 'Model' and Beyond: Placing Welfare Types in Greater China into Context. Social Policy and Society, 13(2), 301-315.

Jisun, K. (2008). 'Self-reliance Program' in South Korea: Focused on the Experiences of the Participants. paper presented in the 17th Biennial Conference of the Asian Studies Association of Australia, Melbourne, 1-3 July.

Jo, J. Y. (2007). The National Basic Livelihood Security System in Korea: Effects on Poverty and Social Development. Doctoral Dissertation. USA: University of California, Berkeley.

Jo, J. Y. (2014). Welfare Policy for a Sustainable Development: Korea's Productive Welfare and the National Basic Livelihood Security System 1

Kementerian Pembangunan Wanita, Keluarga dan Masyarakat.(2015). http://www.kpwkm.gov.my/

Khairul Amri, A. (2015). Pendekatan kebajikan produktif di kalangan usahawan kebajikan di Kedah: Satu penilaian. Tesis Sarjana, Universiti Sains Malaysia.

Laman web Jabatan Kebajikan Masyarakat Kedah. (2015).

Malaysian Fundamental Data. (2014). http://www.rurallink.gov.my/wp-content/uploads/2015/05/1DATA-ASAS-MALAYSIA1.pdf.

Malaysia Social Welfare Department. (2015). Official website.http://www.jkm.gov.my/content.php?pagename=skim bantuan kebajikan\&lang=b

$\underline{\mathrm{m}}$.

Malaysia Social Welfare Department. (2016). Terms of Reference of 2 Years Exit Program Management Pilot Project. Productive Welfare Division. Malaysia Social Welfare Department. Malaysia Tenth Plan. (2010). Malaysia Tenth Plan. 2011-2015. Kuala Lumpur: National Printing.

Misturelli, F. \& Heffernan, C. (2008). What is poverty? A diachronic exploration of the discourse on poverty from the 1970s to the 2000s. The European Journal of Development Research, 20(4), 666-684.

Shostak, A. \& Gomberg, W. (1965). New Perspectives on Poverty. Englewood Cliffs, New Jersey: Prentice-Hall, Inc.

Siti Hadijah C. M., Roslan, A.H. dan Siti Norliza, J. (2012). Indeks Kemiskinan Pelbagai Dimensi Sebagai Alternatif Pengukuran Kemiskinan. Prosiding PERKEM VII, Jilid 1 (2012), 181 - 191.

The World Bank Annual Report. (2008).

World Bank. (2008). The World Bank Annual Report 2008.

World Bank. (2016). Development Goals in an Era of Demographic Change. Global Monitoring Report, $2015 / 2016$. 